\title{
A high proportion of cells carrying trisomy 12 is associated with a worse outcome in patients with chronic lymphocytic leukemia
}

\section{Authors:}

I González-Gascón y Marín ${ }^{1}$, M Hernández-Sánchez ${ }^{2,3}$, AE Rodríguez-Vicente ${ }^{2,3}, \mathrm{C}$ Sanzo $^{4}$, A Aventín ${ }^{5}$, A Puiggros ${ }^{6}, \mathrm{R}_{\text {Collado }}{ }^{7}, \mathrm{C}_{\text {Heras }}{ }^{1}, \mathrm{C}$ Muñoz ${ }^{1}$, J Delgado ${ }^{8}, \mathrm{M}$ Ortega $^{9}$, MT González ${ }^{10}$, I Marugán ${ }^{11}$, I de la Fuente ${ }^{12}$, I Recio ${ }^{13}$, F Bosch $^{9}$, B Espinet ${ }^{6}$, M González ${ }^{2,3}$, JM Hernández-Rivas ${ }^{2,3}$, JA Hernández ${ }^{1,14}$. On behalf of Grupo Español de Leucemia Linfática Crónica (GELLC) and Grupo Cooperativo Español de Citogenética Hematológica (GCECGH).

\section{Institutions:}

${ }^{1}$ Servicio de Hematología, Hospital Universitario Infanta Leonor, Madrid.

${ }^{2}$ Servicio de Hematología, IBSAL-Hospital Universitario de Salamanca.

${ }^{3}$ Centro de Investigación del Cáncer-IBMCC, Universidad de Salamanca (USALCSIC).

${ }^{4}$ Hospital Central de Asturias, Oviedo.

${ }^{5}$ Hospital Santa Creu i Sant Pau, Barcelona.

${ }^{6}$ Hospital del Mar, Barcelona.

${ }^{7}$ Hospital General, Valencia.

${ }^{8}$ Hospital Clinic i Provincial.

${ }^{9}$ Hospital Vall d'Hebron, Barcelona.

${ }^{10}$ Fundación Pública Galega de Medicina Xenomica, Santiago de Compostela

${ }^{11}$ Hospital Clínico Universitario, Valencia

${ }^{12}$ Hospital Rio Hortega, Valladolid

${ }^{13}$ Hospital Nuestra Señora de Sonsoles, Avila

${ }^{14}$ Universidad Complutense, Madrid.

\section{Correspondence:}

José Ángel Hernández Rivas

Servicio de Hematología. Departamento de Medicina. Universidad Complutense de Madrid.

Hospital Universitario Infanta Leonor 
C/ Gran Vía del Este 80,

28031, Madrid, Spain

Email: jahernandezr@salud.madrid.org

Keywords: chronic lymphocytic leukemia, +12, prognosis

Running title: Worse prognosis in CLL patients with a high number +12 cells

Word count: 2324

\section{Acknowledgments}

We thank all the physicians from the Spanish institutions who contributed clinical data.

We are also grateful to Irene Rodríguez, Sara González, Teresa Prieto, M. Ángeles Ramos, Almudena Martín, Ana Díaz, Ana Simón, María del Pozo, Vanesa Gutiérrez and Sandra Pujante from Centro de Investigación del Cáncer, Salamanca, for their technical assistance.

This work was partially supported by grants from the Spanish Fondo de Investigaciones Sanitarias FIS 09/01543, PI12/00281, Proyectos de Investigación del SACYL 355/A/09, COST Action EuGESMA (BM0801), Fundación Manuel Solórzano, Obra Social Banca Cívica (Caja Burgos), Fundación Española de Hematología y Hemoterapia (FEHH), and by a grant (RD12/0036/0069) from Red Temática de Investigación Cooperativa en Cáncer (RTICC), Instituto de Salud Carlos III (ISCIII), Spanish Ministry of Economy and Competitiveness and European Regional Development Fund (ERDF) "Una manera de hacer Europa” and IRON-II collaborative network. The research leading to these results has received funding from the European Union Seventh Framework Programme [FP7/2007-2013] under Grant Agreement n³06242-NGS-PTL. María HernándezSánchez is fully supported by an Ayuda Predoctoral de la Junta de Castilla y León from the Fondo Social Europeo. 


\section{Abstract:}

The prognosis of CLL patients displaying trisomy $12(+12)$ remains unclear.

In this study, we analyzed the influence of the proportion of cells with +12 , and other clinical and biologic factors, in time to first therapy (TTFT) and overall survival (OS), in 289 patients diagnosed with CLL carrying +12. Median OS was 129 months. 174 patients $(60.2 \%)$ presented +12 in $<60 \%$ of cells. TTFT and OS for this subgroup were longer than for the subgroup with +12 in $\geq 60 \%$ of cells, with a median TTFT of 49 months (CI95\%, 39-58) vs 30 months (CI95\%, 22-38) (P=0.001); and a median OS of 159 months (CI95\%, 119-182), vs 96 months (CI95\%, 58-134) $(\mathrm{P}=0.015)$. Other factors associated with a shorter TTFT were: Binet stage, B symptoms, lymphadenopathy, splenomegaly, high lymphocyte count, 11q-, high $\beta_{2}$ microglobulin, and high LDH. In the multivariate analysis, clinical stage, +12 in $\geq 60 \%$ of cells, high lymphocyte count, $\mathrm{B}$ symptoms and 11q- in addition, resulted of significance in predicting shorter TTFT. Significant variables for OS were: Binet stage, lymphadenopathy, splenomegaly, high LDH, high $\beta_{2}$ microglobulin, 11q-, and CD38. In the multivariate analysis, only Binet stage, 11q-, and high $\beta 2$ microglobulin significantly predicted shorter OS. CLL with +12 entails a heterogeneous group with intermediate prognosis. However, a high proportion of cells carrying +12 separates a subgroup of patients with poor outcome. 


\section{Introduction}

Chronic lymphocytic leukemia (CLL) is a heterogeneous disease, with survival times ranging from months to decades [1, 2, 3]. Clonal genomic aberrations can be identified in approximately $80 \%$ of CLL patients by fluorescent in situ hybridization (FISH), and they constitute one of the most important predictors of disease progression and survival. The most common recurrent chromosomal abnormalities include: 13q deletion (13q-); 11q deletion (11q-); trisomy $12(+12)$; and 17p deletion $(17 p-)$, defining five prognostic categories with survival times ranging from 32 months in patients with 17p- to 133 months in patients with 13q- as the sole abnormality [4]. Recently, a new prognostic scoring system which separates CLL patients into four prognostic risk groups has been published: high-risk, harboring TP53 and/or BIRC3 abnormalities (10-year OS: 29\%); intermediate-risk, harboring NOTCH1 and/or SF3B1 mutations and/or del(11q22-q23) (10-year OS: 37\%); low-risk, harboring trisomy 12 or a normal genetics (10-year OS: 57\%); and very low-risk, harboring del(13q) only, whose 10-year OS (69.3\%) did not significantly differ from a matched general population [5].

Trisomy 12 is the third most frequent cytogenetic aberration in CLL, occurring in up to $15-20 \%$. It often appears as the unique cytogenetic alteration (40-70\% of cases with +12), although it can be associated with other chromosomal aberration [6].

The critical genes involved in this aberration remain unknown [7] and it has been associated with an atypical morphology or immunophenotype [8]. CLL patients with this aberration have been classically considered to have an intermediate prognosis [4], although evidence from prospective trials suggests that overall survival is favorable despite progression-free survival may be shorter [7, 9] .

CLL patients with +12 rarely show TP53 mutations and rarely acquire these over time, finding that may partly explain the benign course after treatment $[5,10]$. However, the 
presence of $\mathrm{NOTCH}-1$ mutations can be identified in $30-40 \%$ of patients carrying +12 , and it confers a worse disease outcome in this subset of patients [11, 12, 13, 14].

Several studies demonstrated that the presence of a specific cytogenetic abnormality is not sufficient to identify homogeneous subgroups of patients. Thus, a high proportion of cells carrying 13q14-, or large deletions including RB1 gene are associated with a worse outcome $[15,16,17,18]$. Similar results have been observed regarding 11q-, with a negative prognostic impact when 11q- involves the majority of CLL clone [19], and regarding 17p-, with a worse clinical outcome when a higher percentage of deleted cells is present [20]. Therefore, a multicenter analysis including 289 patients diagnosed with CLL harboring +12 was carried out. We described and compared the clinical and biological characteristics of these patients, and found that a high number of +12 lymphocytes has a bad impact in the clinical outcome. 


\section{Patients and methods}

\section{Patients}

An electronic database containing information from 2,561 patients diagnosed with CLL from 25 Spanish institutions was retrospectively screened. The diagnosis was based according to the World Health Organization Classification of Tumors [21] and International Workshop on CLL guidelines [22]. All (289) cases carrying +12 detected in the routine FISH analysis were selected. Clinical information recorded at diagnosis included age, Binet stage, and physical examination. Analytical parameters included absolute white blood cell and lymphocyte counts, serum lactate dehydrogenase (LDH) and serum beta2-microglobulin (B2M) concentrations. Prognostic factors such as CD38, ZAP70 expression, and mutational status of immunoglobulin heavy chain (IGHV) were collected when available. The study was approved by the local ethics committee and all individuals provided their informed consent.

\section{FISH analysis}

Interphase FISH was performed on peripheral blood samples at the time of diagnosis using commercially available probes for the following regions: 11q22/ATM, 12q13, $13 q 14$ and 17p13/TP53 (Vysis/Abbott Co, Downers Grove, IL, USA). Methods for FISH analysis are described elsewhere [23]. Dual color FISH using differently labeled control probes was performed, and signal screening was carried out on at least 200 cells with well delineated signals. Hybridization was repeated in those slides with less than $80 \%$ cells showing two control-probe signals. The sensitivity limit for the detection of +12 and deletions were $>5 \%$, and $>10 \%$ interphase cells with three signals and one signal respectively.

\section{Statistical analysis}


Statistical analysis was performed using the SPSS 21.0 software package (SPSS, Chicago, IL, USA). The cut-off point for percentage of +12 was selected by dividing the variable into deciles and selecting the most efficient cut-point. The Fischer's exact test and the Chi-squared test were used to determine the relationship between categorical variables. Quantitative variables were compared by using the Student-t test and the Mann-Whitney U test.

OS was calculated from the time of diagnosis to death or last follow-up visit. TTFT was calculated as the interval between diagnosis and the start of first line treatment. OS and TTFT were estimated by the Kaplan-Meier method and assessed by the log-rank test. Univariate and multivariate analysis were performed using Cox regression method. Statistical significance was defined as $\mathrm{P}<0.05$. 


\section{Results}

\section{Patient characteristics}

FISH detected +12 in 355 patients (13.9\%) of the 2,461 patients initially included in the study. The final analysis was limited to 289 cases, after excluding monoclonal B-cell lymphocytosis, cases that acquired +12 as clonal evolution, or with inadequate followup. Median age was 68 years old (range, 22-88 years). A hundred and seventy-eight patients were male (61.6\%). At the time of diagnosis, most cases were classified as stage A (68.9\%), while only 5.2\% were in stage C according to Binet classification [3]. Median white blood cell (WBC) count was $19 \times 10^{9} / \mathrm{L}$, and only $16.3 \%$ of patients presented with $>30 \times 10^{9} / \mathrm{L}$ lymphocytes. Splenomegaly, hepatomegaly, and lymph node involvement were present in $15.5 \%, 5.7 \%$, and 54.1\%, respectively. Regarding IGHV mutation status, $53.8 \%$ of the patients were classified as unmutated. CD38 and ZAP-70 were positive in $37.4 \%$, and $55.8 \%$ of the patients, respectively. Multiple genetic abnormalities detected by FISH were present in 56 cases including: 11q- (3.9\%), 13q(17\%), and $17 \mathrm{p}-(6.1 \%) .78 .2 \%$ of patients were alive at the time of analysis, and median follow up was 41 months (range 1-197 months).

The impact of proportion of cells with +12 on prognosis was assessed by dividing cases into different cutoff values, and we found $60 \%$ as the best predictive cut-off value to divide patients with different clinical outcomes. A total of 174 patients (60.2\%) presented the +12 in $<60 \%$ of cells; whereas the remaining 115 patients (39.8 \%) carried +12 in $\geq 60 \%$ of cells. Cases with a higher $(\geq 60 \%)$ proportion of cells with +12 , presented with a higher WBC $(\mathrm{P}=0.001)$, lymphocyte count $(\mathrm{P}=0.006)$, LDH $(\mathrm{P}=0.03)$, size of spleen $(\mathrm{P}=0.001)$, and more advanced Binet stage $(\mathrm{P}=0.04)$ (Table 1$)$.

\section{Time to first therapy}


In our cohort of 289 patients, 175 (60.6\%) were treated during follow up, and median TTFT was 42 months (CI95\%, 34-49 months). 51.2\% of patients in the group with lower proportion of +12 required treatment, compared with $75.7 \%$ of patients in the group with $\geq 60 \%$ of cells showing $+12(\mathrm{P}<0.001)$.

As shown in figure 1, we found that median TTFT was 49 months (CI95\%, 39-58 months) in cases with +12 in $<60 \%$ of cells compared with 30 months (CI95\%, 22-38 months) in cases with $\geq 60 \%$ ( $\mathrm{P}=0.001$ ). Other significant prognostic variables for TTFT in the univariate analysis were (Figure $1 \mathrm{~B}-\mathrm{H})$ : Binet stage $(\mathrm{P}<0.0001)$, B symptoms ( $\mathrm{P}<0.0001)$, lymphadenopathy $(\mathrm{P}<0.0001)$, splenomegaly $(\mathrm{P}<0.0001)$, high lymphocyte count $(\mathrm{P}<0.0001)$, high $\mathrm{B} 2 \mathrm{M}(\mathrm{P}=0.02)$, and high LDH $(\mathrm{P}=0.01)$ (Table 2$)$. In the multivariate analysis, a shorter TTFT was predicted by Binet stage $(\mathrm{P}=0.002), \geq 60 \%$ of cells with $+12(\mathrm{P}=0.013)$, high lymphocyte count $(\mathrm{P}=0.04)$, B symptoms $(\mathrm{P}=0.009)$ and 11q- in addition to $+12(\mathrm{P}=0.002)$ (Table 3$)$.

\section{Overall survival}

At the time of analysis, 69 patients (21.8\%) had died. Median OS was 129 months (CI95\%, 100-158 months). A total of $16.7 \%$ of patients in the group with lower proportion of +12 died compared with $29.6 \%$ of patients in the group with $\geq 60 \%$ of cells showing $+12(\mathrm{P}=0.009)$ (Table 1$)$.

Regarding OS based on the percentage of cells with +12 , cases with less than $60 \%$ of cells with +12 had a significantly longer OS,159 months (CI95\%, 119-182 months) compared to patients with a higher proportion of cells carrying +12, 96 months (CI95\%, 58-134 months) $(\mathrm{P}=0.015)$ (Figure $2 \mathrm{~A})$. Other variables that also showed a significant impact in OS in the univariate analysis were (Figure 2B-G): advanced Binet stage $(\mathrm{P}<0.0001)$, lymphadenopathy $(\mathrm{P}=0.001)$, splenomegaly $(\mathrm{P}=0.001)$, high LDH 
( $\mathrm{P}=0.009)$, high $(\mathrm{P}<0.0001)$, and $\mathrm{CD} 38$ ( $\mathrm{P}=0.04)$, (Table 4). In the multivariate analysis, only Binet stage $(\mathrm{P}=0.04), 11 \mathrm{q}$ - in addition to $+12(\mathrm{P}=0.01)$ and high $\mathrm{B} 2 \mathrm{M}$ $(\mathrm{P}=0.03)$ resulted significant in predicting a shorter OS (Table 5).

\section{Sole +12 compared with additional cytogenetic abnormalities}

In our group of 289 patients harboring +12, 56 cases (19\%) presented additional cytogenetic abnormalities distributed as detailed as follows: $13 q-(n=34) ; 17 p-(n=11)$; $11 q-(n=5) ; 11 q-$ and 13q- $(n=3) ; 17 p-$ and $13 q-(n=2)$; and $17 p-$ and $11 q-(n=1)$; (Supporting information Table S1). Distribution between the different cytogenetic subgroups and the percentage of cells with +12 was similar, as shown in Table 1 .

TTFT was shorter in the group of cases with +12 and 11q- compared with cases with +12 as a unique aberration (23 months [CI95\%, 9-37] vs 44 months [CI95\%, 36-52] $[\mathrm{P}=0.02]$ ) (Supporting information Figure $\mathrm{S} 1 \mathrm{~A}$ ). A shorter OS was observed when simultaneous +12 and 11q- were present (44 months [CI95\%, 26-62] vs 159 months [CI95\%, 92-226] [P=0.02]) (Supporting information Figure S1B).

We could not find any difference in TTFT or OS when +12 was accompanied by $17 p-$ or 13q-. It is remarkable that most of the patients with $11 q-(7 / 9)$ presented it in $\geq$ than $25 \%$ of $11 q$ deleted nuclei. 


\section{Discussion}

Cytogenetic abnormalities confer an important prognostic value in CLL [3]. However, recent studies have demonstrated that cytogenetic groups might be heterogeneous, and that the percentage of cells that display a specific abnormality could be related to the prognosis of these subgroups [15, 19, 209]. These observations have not been confirmed before in patients carrying +12 . For these reasons, we performed a multicentric analysis of patients diagnosed with CLL and +12 focusing on the prognostic value that the percentage of cells with this abnormality may imply. We observed that patients with +12 constitute a heterogeneous group with intermediate prognosis, with a poor outcome in the subgroup of patients with a higher proportion of cells carrying +12 .

Trisomy 12 was present in $13.5 \%$ of the patients, being the median OS of 129 months, and median TTFT of 42 months. These findings are consistent with previous publications that estimate frequency of +12 around $15-20 \%$, with a median OS of 111 months, and a median TTFT of 32 months [4]. The other clinical characteristics of the present series, such as the median age (68 years), with a male predominance; the predominance of low lymphocyte count (83\%), low $\beta_{2}$ microglobulin levels (71\%), early Binet stages (71\%), low levels of CD38 (63\%), and absence of significant organomegaly, are also in accordance to previous studies [4, 7].

The percentage of cells displaying +12 identified 2 subgroups of patients with different prognosis. Interestingly, patients with a higher proportion of +12 cells presented with higher WBC and lymphocyte count; higher levels of LDH and $\beta_{2}$ microglobulin; more advanced Binet stages; and splenomegaly. More patients with a high proportion of cells with +12 needed treatment or died during follow up. 
Of note, the group of patients with +12 in $<60 \%$ of their cells, showed a significantly longer TTFT and OS. Moreover, in the multivariate analysis, the independent effect of this covariate remained on TTFT.

To better define prognostic features among all the group of patients with +12 , several factors predicting a shorter TTFT were identified. Thus, advanced Binet clinical stage, B symptoms, lymphadenopathy, splenomegaly, high lymphocyte count, and high LDH were associated with shorter TTFT. It is remarkable that the presence of $>60 \%$ of cells with +12 , advanced Binet stage, high lymphocyte count, and B symptoms remained significantly associated with a worse TTFT in the multivariate analysis. These results are similar to the published studies in the overall setting of CLL cases $[4,8,13]$.

We also found that similar factors were associated with a shorter OS, including advanced Binet stage, lymphadenopathy, splenomegaly, high LDH, high $\beta_{2}$ microglobulin, and expression of CD38. However, only advance Binet stage, and high $\beta_{2}$ microglobulin remained independently significant in predicting OS.

As speculated with other cytogenetic abnormalities, it may be possible that the greatest number of losses in 13q 11q, or 17p deletions or a high percentage of cells with +12 , translates genetic instability that makes the outcome of these patients worse. In our series we found that $60 \%$ of cells with +12 was the better cut-off with clinical significance, after trying different thresholds. However, further studies preferably in a prospective context need to be performed to validate this limit.

We could not find predictive value regarding other important prognostic factors such as IGHV mutation status, and expression of ZAP-70. Nevertheless, data were collected retrospectively, and these factors were not analyzed in the whole series of patients.

Coexistence of other cytogenetic abnormalities in addition to +12 was rare in our cohort, and it is consistent with previous publications $[6,7,10]$. Only $19 \%$ of patients 
presented other cytogenetic abnormalities, being 13q- the most frequent followed by 17p- and 11q-. We analyzed TTFT and OS in the different cytogenetic abnormalities, and we found a significantly shorter TTFT and OS in the group of patients with 11q-. This covariate preserved its effect in the multivariate analysis. We failed to observe these findings in the subgroup of patients with $17 \mathrm{p}-$. Moreover, only a tendency to a longer OS in patients with 13q- was observed. It is noteworthy that even though 11qwas only present in 9 patients, nearly all of them presented it in $\geq$ than $25 \%$ of $11 \mathrm{q}$ deleted nuclei, which has previously been associated with a worse outcome [8]. However, larger studies with more patients are needed to ascertain these findings, and address the relationship between +12 and other cytogenetic abnormalities.

To summarize, our findings suggest that the percentage of cells carrying +12 influences the outcome of these patients. We demonstrated that a high proportion of cells with +12 detected by FISH is associated with a short OS and TTFT. Our results suggest the need to consider the percentage of cells with +12 as an important prognostic factor, in future prognosis scales.

\section{Conflict of interests}

The authors declare that there is no conflict of interests regarding the publication of this article. 


\section{References}

1. Dighiero G, Hamblin TJ. Chronic lymphocytic leukaemia. Lancet 2008; 371: 101729.

2. Rai KR, Sawitsky A, Cronkite EP, Chanana AD, Levy RN, Pasternack BS. Clinical staging of chronic lymphocytic leukemia. Blood 1975; 46: 219-34.

3. Binet JL, Auquier A, Dighiero G, Chastang C, Piguet H, Goasguen J, et al. A new prognostic classification of chronic lymphocytic leukemia derived from a multivariate survival analysis. Cancer 1981; 48: 198-206.

4. Döhner H, Stilgenbauer S, Benner A, Leupolt E, Kröber A, Bullinger L, et al. Genomic aberrations and survival in chronic lymphocytic leukemia. $N$ Engl J Med 2000; 343: 1910-6.

5. Rossi D, Rasi S, Spina V, Bruscaggin A, Monti S, Ciardullo C, et al. Integrated mutational and cytogenetic analysis identifies new prognostic subgroups in chronic lymphocytic leukemia. Blood 2013; 218:1403-12.

6. Puiggros A, Blanco G, Espinet B. Genetic abnormalities in chronic lymphocytic leukemia: where we are and where we go. BioMed Res Int 2014;2014:435983.

7. Rodríguez-Vicente AE, Díaz MG, Hernández-Rivas JM. Chronic lymphocytic leukemia: a clinical and molecular heterogenous disease. Cancer Genet 2013; 206: 49-62.

8. Matutes E, Oscier D, Garcia-Marco J, Ellis J, Copplestone A, Gillingham R, et al. +12 defines a group of CLL with atypical morphology: correlation between cytogenetic, clinical and laboratory features in 544 patients. Br J Haematol 1996; 92: 382-8.

9. Hallek M, Fischer K, Fingerle-Rowson G, Fink AM, Busch R, Mayer J, et al. Addition of rituximab to fludarabine and cyclophosphamide in patients with chronic 
lymphocytic leukaemia: a randomised, open-label, phase 3 trial. Lancet 2010; 376: $1164-74$.

10. Zenz T, Vollmer D, Trbusek M, Smardova J, Benner A, Soussi T, et al. TP53 mutation profile in chronic lymphocytic leukemia: evidence for a disease specific profile from a comprehensive analysis of 268 mutations. Leukemia 2010; 24 :20729.

11. Villamor N, Conde L, Martínez-Trillos A, Cazorla M, Navarro A, Beà S, et al. NOTCH1 mutations identify a genetic subgroup of chronic lymphocytic leukemia patients with high risk of transformation and poor outcome. Leukemia 2012; 27 :1100-6.

12. Balatti V, Bottoni A, Palamarchuk A, Alder H, Rassenti LZ, Kipps TJ, et al. NOTCH1 mutations in CLL associated with +12. Blood 2011; 119: 329-31.

13. Balatti V, Lerner S, Rizzotto L, Rassenti LZ, Bottoni A, Palamarchuk A, et al. +12 CLLs progress through NOTCH1 mutations. Leukemia 2013; 273: 740-3.

14. Weissmann S, Roller A, Jeromin S, Hernández M, Abáigar M, Hernández-Rivas JM, et al. Prognostic impact and landscape of NOTCH1 mutations in chronic lymphocytic leukemia (CLL): a study on 852 patients. Leukemia 2013; 12: 2393-6.

15. Hernández JA, Rodríguez AE, González M, Benito R, Fontanillo C, Sandoval V, et al. A high number of losses in 13q14 chromosome band is associated with a worse outcome and biological differences in patients with B-cell chronic lymphoid leukemia. Haematologica 2009; 94: 364-71.

16. Hernández JA, González M, Hernández JM. Chronic lymphocytic leukemia. Med Clínica 2010; 135: 172-8. 
17. Dal Bo M, Rossi FM, Rossi D, Deambrogi C, Bertoni F, Del Giudice I, et al. 13q14 deletion size and number of deleted cells both influence prognosis in chronic lymphocytic leukemia. Genes Chromosomes Cancer 2011; 50 :633-43.

18. Van Dyke DL, Shanafelt TD, Call TG, Zent CS, Smoley SA, Rabe KG, et al. A comprehensive evaluation of the prognostic significance of $13 q$ deletions in patients with B-chronic lymphocytic leukaemia. Br J Haematol 2010; 148: 544-50.

19. Marasca R, Maffei R, Martinelli S, Fiorcari S, Bulgarelli J, Debbia G, et al. Clinical heterogeneity of de novo 11q deletion chronic lymphocytic leukaemia: prognostic relevance of extent of $11 \mathrm{q}$ deleted nuclei inside leukemic clone. Hematol Oncol 2013; 31: 348-55.

20. Tam CS, Shanafelt TD, Wierda WG, Abruzzo LV, Van Dyke DL, O’Brien S, et al. De novo deletion 17p13.1 chronic lymphocytic leukemia shows significant clinical heterogeneity: the M. D. Anderson and Mayo Clinic experience. Blood 2009; 114: 957-64.

21. Harris NL, Jaffe ES, Diebold J, Flandrin G, Muller-Hermelink HK, Vardiman J, et al. World Health Organization classification of neoplastic diseases of the hematopoietic and lymphoid tissues: report of the Clinical Advisory Committee meeting-Airlie House, Virginia, November 1997. J Clin Oncol Off J Am Soc Clin Oncol 1999; 17: 3835-49.

22. Hallek M, Cheson BD, Catovsky D, Caligaris-Cappio F, Dighiero G, Döhner H, et al. Guidelines for the diagnosis and treatment of chronic lymphocytic leukemia: a report from the International Workshop on Chronic Lymphocytic Leukemia updating the National Cancer Institute-Working Group 1996 guidelines. Blood 2008; 111: 5446-56. 
23. González MB, Hernández JM, García JL, Lumbreras E, Castellanos M, Hernández $\mathrm{JM}$, et al. The value of fluorescence in situ hybridization for the detection of $11 \mathrm{q}$ in multiple myeloma. Haematologica 2004; 89: 1213-8. 


\section{Tables}

Table 1. Clinical and biological characteristics of the whole series of 289 patients with +12 at diagnosis, according to the percentage of cells with +12 detected by FISH: < $60 \%$ or $\geq 60 \%$.

\begin{tabular}{|c|c|c|c|c|c|}
\hline Characteristic & $\begin{array}{c}+12<60 \% \\
n=174\end{array}$ & $\begin{array}{c}+12 \geq 60 \% \\
n=115\end{array}$ & p value & Global series & $\%$ \\
\hline Age, years. Median (range) & $69(34-88)$ & $68(25-87)$ & 0.56 & $68(25-88)$ & \\
\hline \multicolumn{6}{|l|}{ Sex } \\
\hline Male & 104 & 74 & 0.45 & 178 & 61.6 \\
\hline Female & 70 & 41 & & 111 & 38.4 \\
\hline $\begin{array}{l}\text { White blood cells ( } n=281 \text { ), } \\
\text { (range) } \times 10^{9} / \mathrm{L}\end{array}$ & $\begin{array}{c}16.2(4.5- \\
294.2)\end{array}$ & $\begin{array}{c}23.8(5.9- \\
276.0) \\
\end{array}$ & 0.001 & $\begin{array}{l}19.0(4.5- \\
294.2) \\
\end{array}$ & \\
\hline \multicolumn{6}{|l|}{ Lymphocytes ( $n=279$ ) } \\
\hline$\leq 30 \times 10^{9} / \mathrm{L}$ & 149 & 86 & 0.006 & 232 & 83.2 \\
\hline$>30 \times 10^{9} / \mathrm{L}$ & 20 & 27 & & 47 & 16.8 \\
\hline \multicolumn{6}{|l|}{ LDH $(n=276)$} \\
\hline Normal & 114 & 59 & 0.03 & 173 & 62.7 \\
\hline High & 54 & 49 & & 103 & 37.3 \\
\hline \multicolumn{6}{|l|}{$\beta_{2}$ microglobulin $(n=246)$} \\
\hline Normal & 110 & 65 & 0.08 & 175 & 71.1 \\
\hline High & 36 & 35 & & 71 & 28.9 \\
\hline \multicolumn{6}{|l|}{ Binet stage $(n=280)$} \\
\hline$A$ & 128 & 71 & 0.04 & 199 & 71.1 \\
\hline B & 34 & 32 & & 66 & 23.6 \\
\hline $\mathrm{C}$ & 6 & 9 & & 15 & 5.4 \\
\hline \multicolumn{6}{|l|}{ Lymphadenopathy ( $n=244)$} \\
\hline No & 70 & 42 & 0.34 & 112 & 45.9 \\
\hline$\leq 2$ areas & 31 & 22 & & 53 & 21.7 \\
\hline$>2$ areas & 42 & 37 & & 79 & 32.4 \\
\hline \multicolumn{6}{|l|}{ Splenomegaly $(n=279)$} \\
\hline Yes & 15 & 28 & 0.001 & 43 & 15.5 \\
\hline No & 152 & 84 & & 236 & 84.5 \\
\hline \multicolumn{6}{|l|}{ Hepatomegaly $(n=278)$} \\
\hline Yes & 7 & 9 & 0.38 & 262 & 5.7 \\
\hline No & 160 & 102 & & 16 & 94.3 \\
\hline \multicolumn{6}{|l|}{$\begin{array}{l}\text { IGHV mutation status } \\
(\mathrm{n}=80)\end{array}$} \\
\hline Mutated & 22 & 19 & 0.74 & 37 & 46.3 \\
\hline Unmutated & 24 & 15 & & 43 & 53.8 \\
\hline \multicolumn{6}{|l|}{ CD38 (n=190) } \\
\hline Positive & 43 & 28 & 0.99 & 71 & 37.4 \\
\hline Negative & 71 & 48 & & 119 & 62.6 \\
\hline
\end{tabular}




\begin{tabular}{|c|c|c|c|c|c|}
\hline \multicolumn{6}{|l|}{ ZAP-70 (n=95) } \\
\hline Positive & 32 & 21 & 0.91 & 53 & 55.8 \\
\hline Negative & 24 & 18 & & 42 & 44.2 \\
\hline \multicolumn{6}{|c|}{$\begin{array}{l}\text { Therapy during follow-up } \\
(\mathrm{n}=287)\end{array}$} \\
\hline Yes & 88 & 87 & $<0.001$ & 175 & 61 \\
\hline No & 84 & 28 & & 112 & 39 \\
\hline \multicolumn{6}{|c|}{ Died during follow-up } \\
\hline Yes & 29 & 34 & 0.009 & 63 & 21.8 \\
\hline No & 145 & 81 & & 226 & 78.2 \\
\hline \multicolumn{6}{|c|}{ Other FISH abnormalities } \\
\hline $11 q-(n=225)$ & 7 & 2 & 0.2 & 9 & 3.9 \\
\hline $13 q-(n=225)$ & 22 & 17 & 0.5 & 39 & 17 \\
\hline $17 p-(n=224)$ & 10 & 4 & 0.3 & 14 & 6.1 \\
\hline
\end{tabular}

Table 2. Univariate Cox regression analysis of time to first therapy (TTFT).

\begin{tabular}{|c|c|c|c|c|}
\hline Variable & & $\begin{array}{c}\text { Median } \\
\text { TTFT } \\
\text { (months) }\end{array}$ & $95 \% \mathrm{Cl}$ & P value \\
\hline \multirow{2}{*}{ Percentage of cells with +12} & $<60 \%$ & 49 & $40-58$ & 0.001 \\
\hline & $\geq 60 \%$ & 30 & $22-38$ & \\
\hline \multirow[t]{2}{*}{ Sex } & Male & 33 & $24-42$ & 0.2 \\
\hline & Female & 46 & $39-53$ & \\
\hline \multirow[t]{2}{*}{ Lymphocytes } & $\leq 30 \times 10^{9} / \mathrm{L}$ & 46 & $36-56$ & $<0.0001$ \\
\hline & $>30 \times 10^{9} / L$ & 20 & $15-25$ & \\
\hline \multirow[t]{2}{*}{ B symptoms } & Absent & 45 & $32-55$ & $<0.0001$ \\
\hline & Present & 7 & $0-18$ & \\
\hline \multirow[t]{2}{*}{ Lactate dehydrogenase } & Normal & 52 & $36-68$ & 0.001 \\
\hline & High & 31 & $18-43$ & \\
\hline \multirow[t]{2}{*}{$\beta_{2}$ microglobulin } & Normal & 48 & $36-60$ & 0.002 \\
\hline & High & 30 & $25-35$ & \\
\hline \multirow[t]{2}{*}{ Binet stage } & Early & 53 & $44-63$ & $<0.0001$ \\
\hline & Advanced & 21 & $14-28$ & \\
\hline \multirow[t]{3}{*}{ Lymphadenopathy } & No & 56 & $41-71$ & $<0.0001$ \\
\hline & $\leq 2$ areas & 43 & $25-60$ & \\
\hline & $>2$ areas & 22 & $16-27$ & \\
\hline \multirow[t]{2}{*}{ Splenomegaly } & Absent & 45 & $37-53$ & $<0.0001$ \\
\hline & Present & 22 & $18-27$ & \\
\hline \multirow[t]{2}{*}{ Hepatomegaly } & Yes & 40 & $31-49$ & 0.7 \\
\hline & No & 37 & $24-50$ & \\
\hline \multirow[t]{2}{*}{ IGHV mutation status } & Yes & 52 & $17-87$ & 0.07 \\
\hline & No & 31 & $23-38$ & \\
\hline
\end{tabular}




\begin{tabular}{|lllll|} 
& Negative & 48 & $40-56$ & 0.1 \\
& Positive & 30 & $18-42$ & \\
\hline ZAP-70 & Negative & 42 & $16-68$ & 0.4 \\
& Positive & 37 & $23-51$ & \\
\hline 13q- & Present & 49 & $38-59$ & 0.2 \\
& Absent & 37 & $26-47$ & \\
\hline 11q- & Present & 23 & $9-37$ & 0.002 \\
& Absent & 44 & $36-52$ & \\
\hline 17p- & Present & 42 & $20-64$ & 0.3 \\
& Absent & 44 & $35-53$ & \\
\hline
\end{tabular}

$95 \% \mathrm{Cl}, 95 \%$ confidence interval.

Table 3. Multivariate Cox regression of time to first therapy (TTFT).

\begin{tabular}{|lccc|}
\hline Variable & $\begin{array}{c}\text { Hazard } \\
\text { ratio }\end{array}$ & $\mathbf{9 5 \% C l}$ & P value \\
\hline $\mathbf{+ 1 2} \geq \mathbf{6 0} \%$ of cells & 1.739 & $1.126-2.687$ & 0.013 \\
Lymphocytes $>\mathbf{3 0} \times \mathbf{1 0} \mathbf{~} \mathbf{L}$ & 1.801 & $1.025-3.162$ & 0.041 \\
B symptoms & 3.038 & $1.315-7.018$ & 0.009 \\
High $\boldsymbol{\beta}_{2}$ microglobulin & 1.426 & $0.857-2.374$ & 0.17 \\
Advanced Binet stage & 2.120 & $1.311-3.429$ & 0.002 \\
High LDH & 1.065 & $0.684-1.660$ & 0.78 \\
Splenomegaly & 0.489 & $0.201-1.188$ & 0.11 \\
$\mathbf{1 1 q -}$ & 4.327 & $1.737-10.782$ & 0.002 \\
\hline
\end{tabular}

$95 \% \mathrm{Cl}, 95 \%$ confidence interval

Table 4. Univariate Cox regression analysis of overall survival (OS)

\begin{tabular}{|c|c|c|c|c|}
\hline Variable & & $\begin{array}{l}\text { Median OS } \\
\text { (months) }\end{array}$ & $95 \% \mathrm{Cl}$ & $P$ value \\
\hline \multicolumn{5}{|l|}{ Percentage of cells with } \\
\hline \multirow[t]{2}{*}{+12} & $<60 \%$ & 159 & $100-148$ & 0.015 \\
\hline & $\geq 60 \%$ & 96 & $58-134$ & \\
\hline \multirow[t]{2}{*}{ Sex } & Male & 129 & $82-176$ & 0.9 \\
\hline & Female & 129 & Not reached & \\
\hline \multirow[t]{2}{*}{ Lymphocytes } & $\leq 30 \times 10^{9} / \mathrm{L}$ & 129 & $102-156$ & 0.05 \\
\hline & $>30 \times 10^{9} / \mathrm{L}$ & 96 & $55-137$ & \\
\hline \multirow[t]{2}{*}{ B symptoms } & Absent & 129 & $118-140$ & 0.3 \\
\hline & Present & Not reached & Not reached & \\
\hline \multirow[t]{2}{*}{ Lactate dehydrogenase } & Normal & 197 & Not reached & 0.009 \\
\hline & High & 81 & $60-101$ & \\
\hline \multirow[t]{2}{*}{$\beta_{2}$ microglobulin } & Normal & 159 & $111-207$ & $<0.0001$ \\
\hline & High & 76 & $45-107$ & \\
\hline \multirow[t]{2}{*}{ Binet stage } & Early & 159 & $131-187$ & $<0.0001$ \\
\hline & Advanced & 79 & $48-109$ & \\
\hline Lymphadenopathy & No & 159 & 123-195 & 0.001 \\
\hline
\end{tabular}




\begin{tabular}{|llccc|} 
& $>2$ areas & 79 & $51-106$ & \\
\hline Splenomegaly & Absent & 129 & $102-155$ & 0.001 \\
& Present & 121 & Not reached & \\
\hline Hepatomegaly & Yes & 129 & $101-157$ & 0.2 \\
& No & Not reached & Not reached & \\
\hline \multirow{2}{*}{ IGHV mutation status } & Yes & 159 & Not reached & 0.6 \\
& No & Not reached & Not reached & \\
\hline CD38 & Negative & 159 & $104-214$ & 0.04 \\
& Positive & 129 & $77-181$ & \\
\hline 13q- & Present & 129 & $230-227$ & 0.4 \\
& Absent & 159 & $80-237$ & \\
\hline 11q- & Present & 44 & $26-61$ & 0.018 \\
& Absent & 159 & $92-226$ & \\
\hline $\mathbf{1 7 p -}$ & Present & 81 & $1.1-160$ & 0.4 \\
& Absent & 159 & $91-226$ & \\
\hline
\end{tabular}

95\% CI, 95\% confidence interval

Table 5. Multivariate Cox regression of overall survival (OS).

\begin{tabular}{|lccc|}
\hline Variable & $\begin{array}{c}\text { Hazard } \\
\text { ratio }\end{array}$ & $\mathbf{9 5 \% C l}$ & P value \\
\hline & & $0.834-$ & \\
$\mathbf{+ 1 2} \geq \mathbf{6 0 \%}$ of cells & 1.631 & 3.188 & 0.15 \\
& & $1.070-$ & \\
High $\boldsymbol{\beta}_{2}$ microglobulin & 2.259 & 4.770 & 0.03 \\
& & $1.023-$ & \\
Advanced Binet stage & 1.717 & 2.881 & 0.04 \\
& & $0.685-$ & \\
High LDH & 1.451 & 3.074 & 0.33 \\
& & $1.420-$ & \\
11q- & 5.097 & 18.289 & 0.01 \\
\hline
\end{tabular}

95\% CI, 95\% confidence interval

\section{Legends}

Figure 1. Kaplan-Meier curves for time to first therapy (TTFT) in 289 patients with +12 and: percentage of $+12(<v s \geq 60 \%)$ (A); Binet stage (B); B symptoms (C); Lymphadenopathy (D); Splenomegaly (E); Lymphocyte count (F); LDH (G); and $\beta_{2}$ microglobulin (B2M) $(\mathrm{H})(\mathrm{P}<0.005$; log-rank test).

1A 


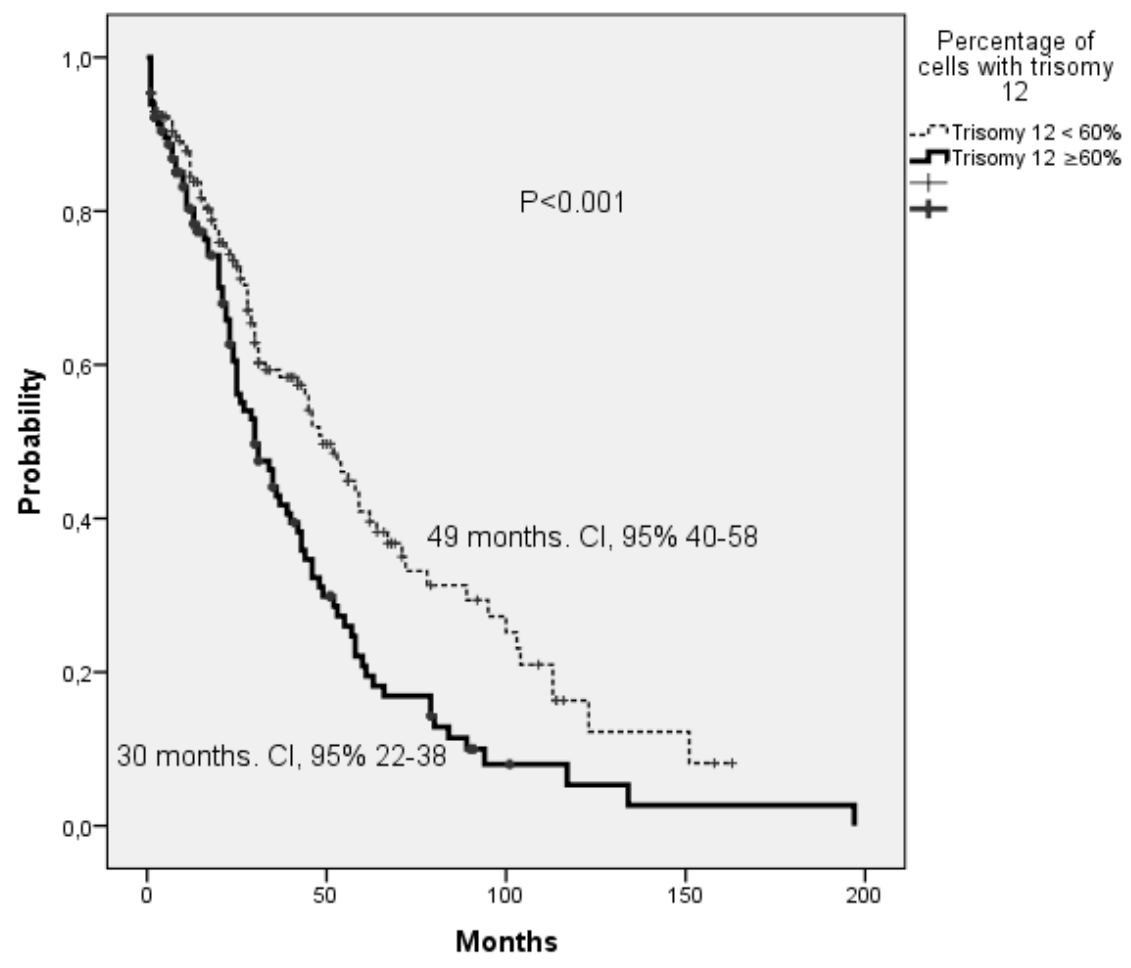

1B

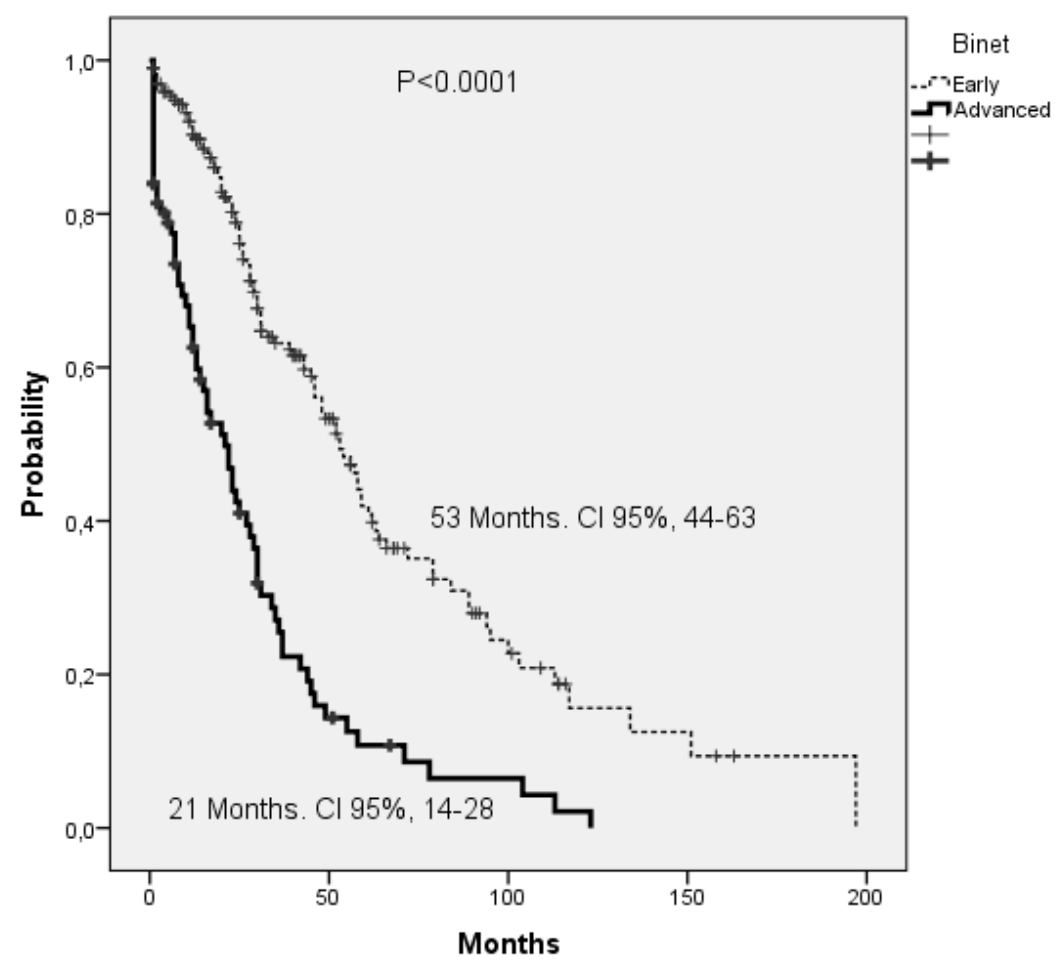

1C 


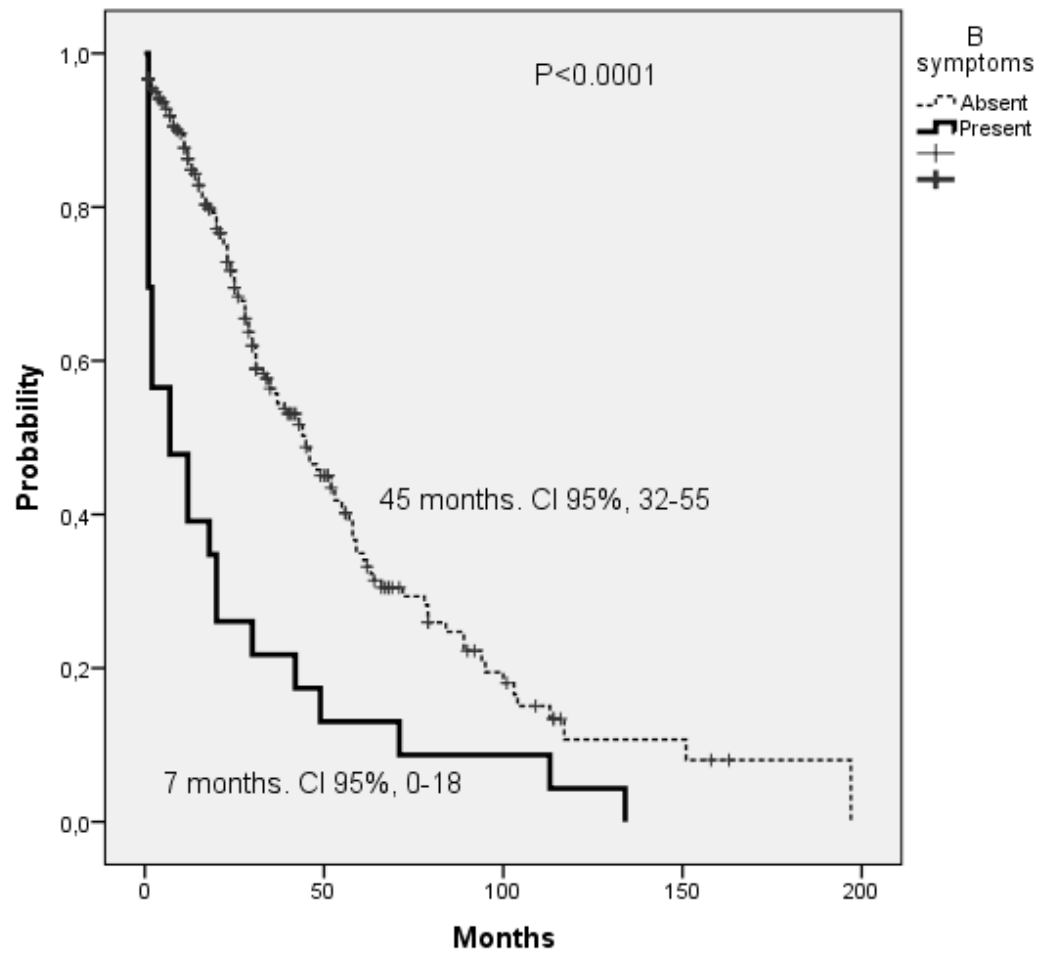

1D

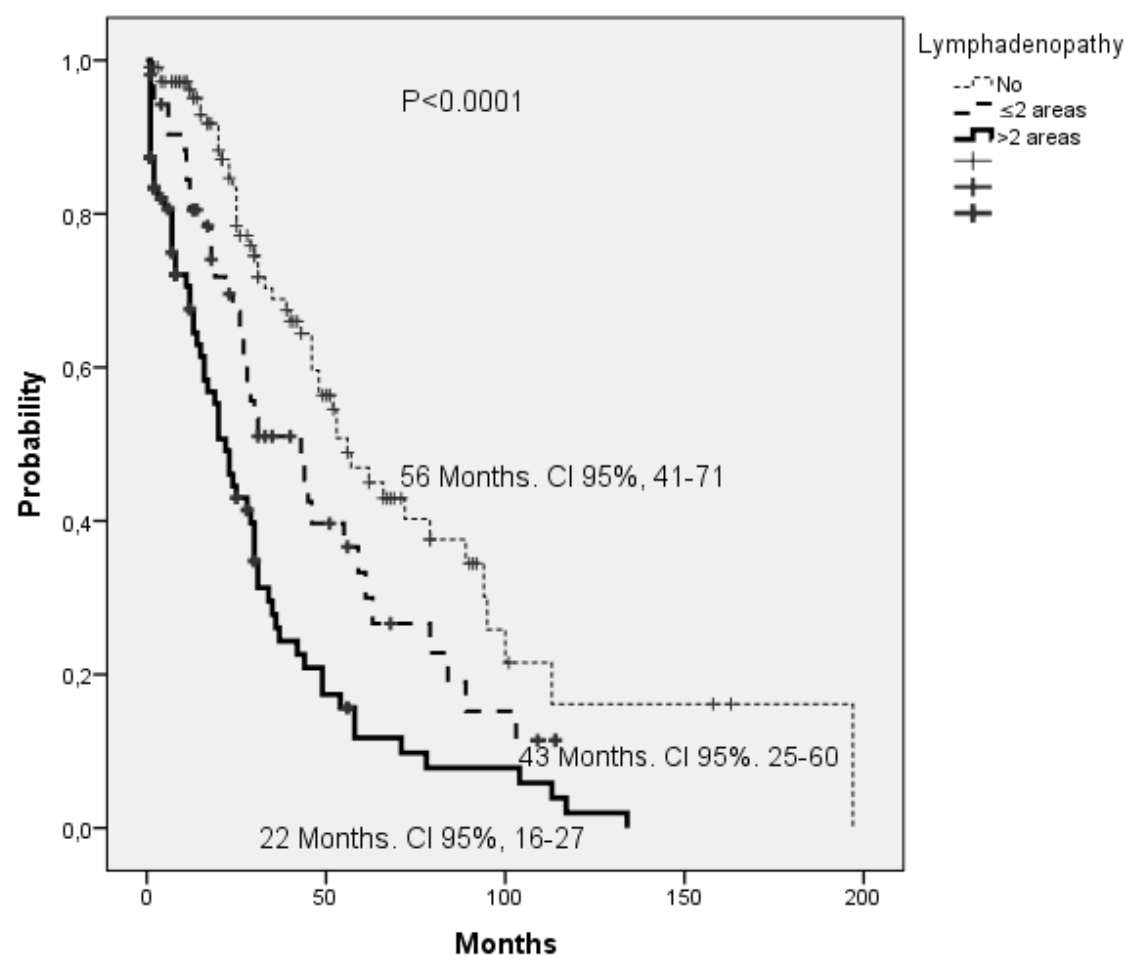

1E 


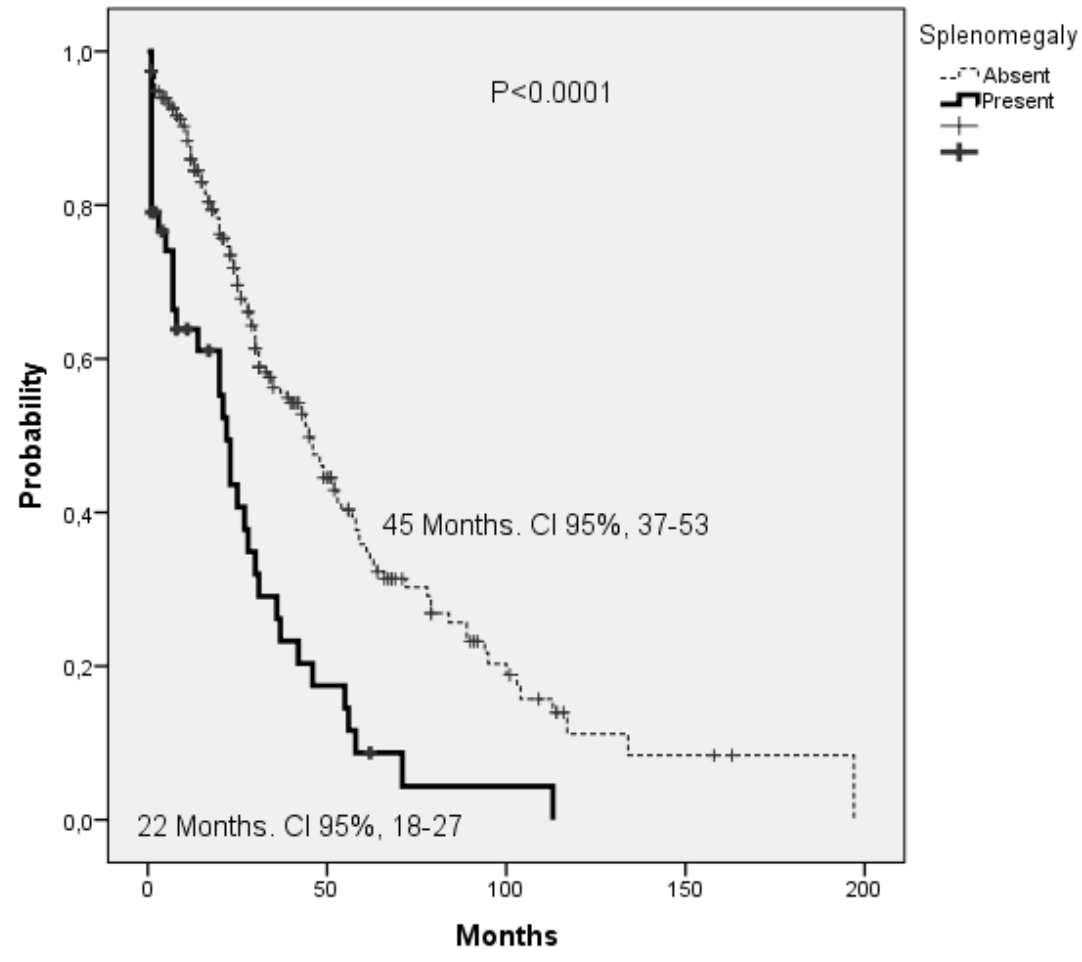

1F

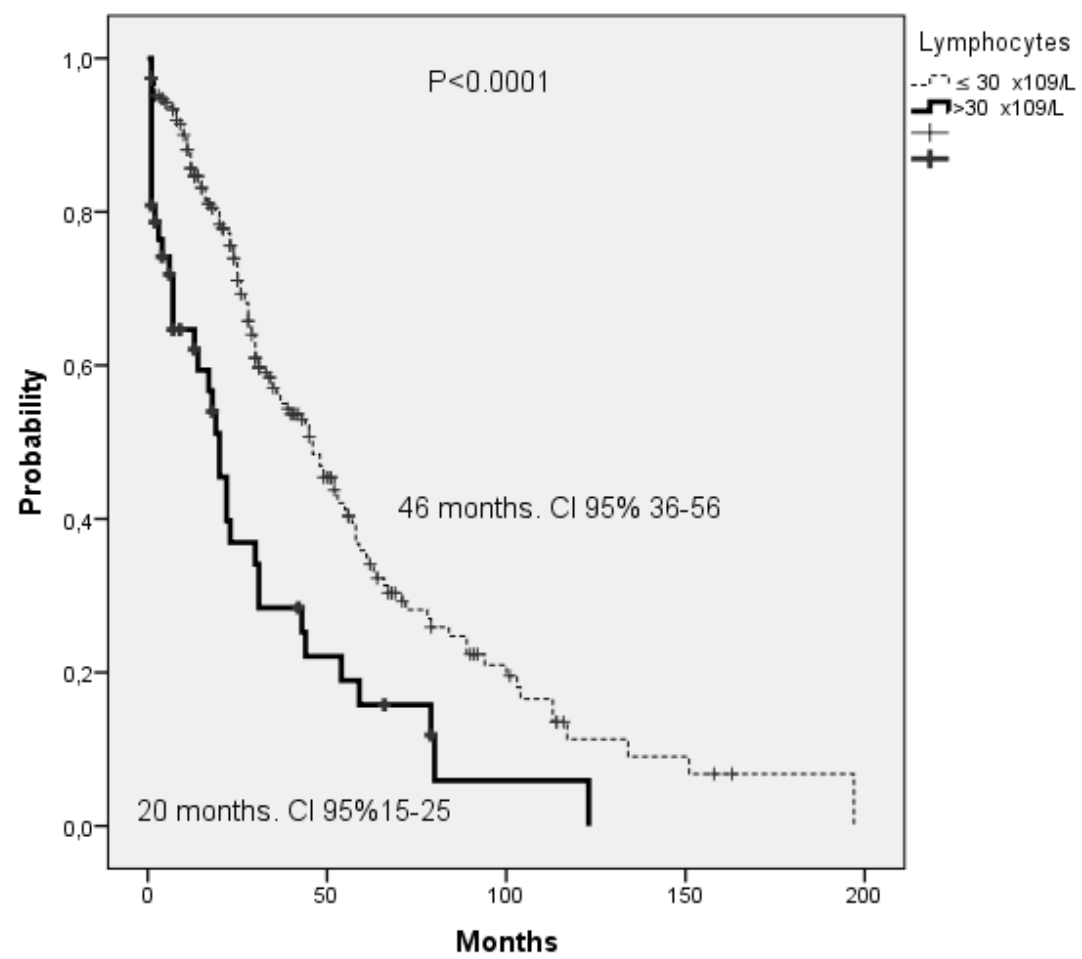

$1 G$ 


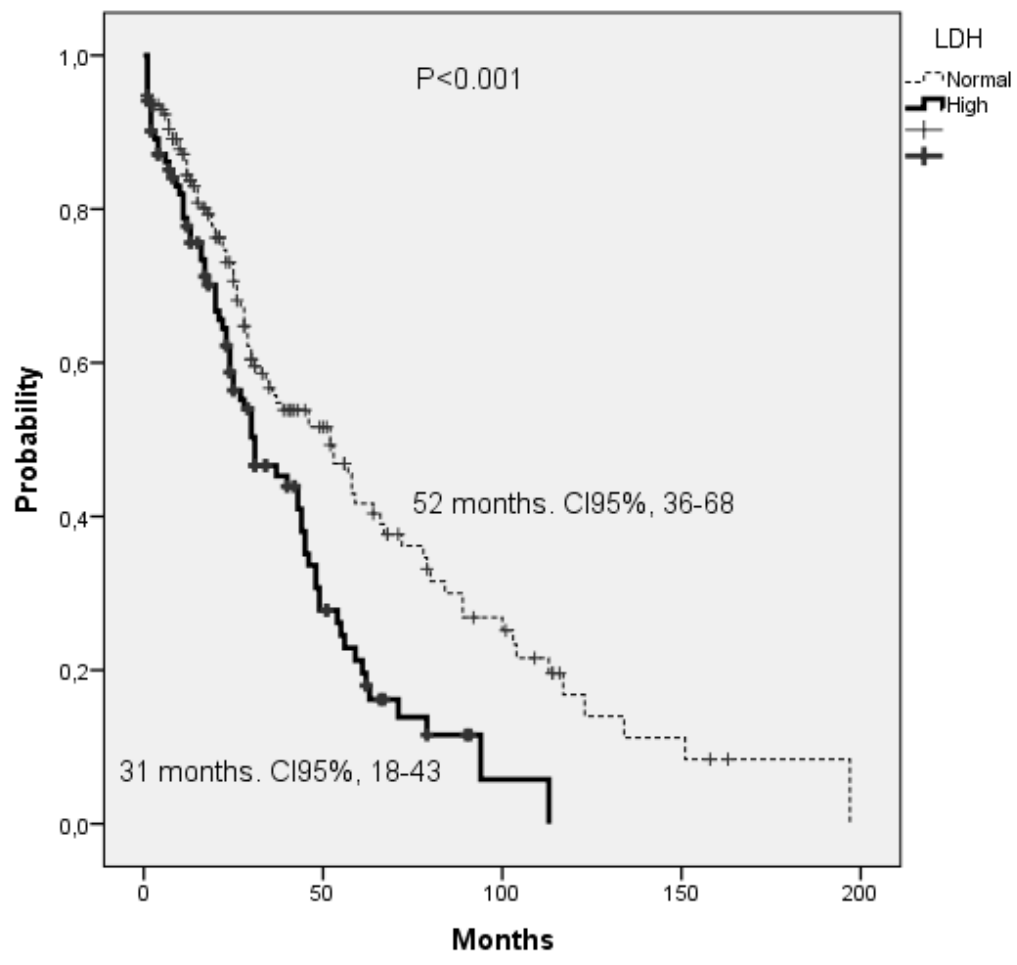

$1 \mathrm{H}$

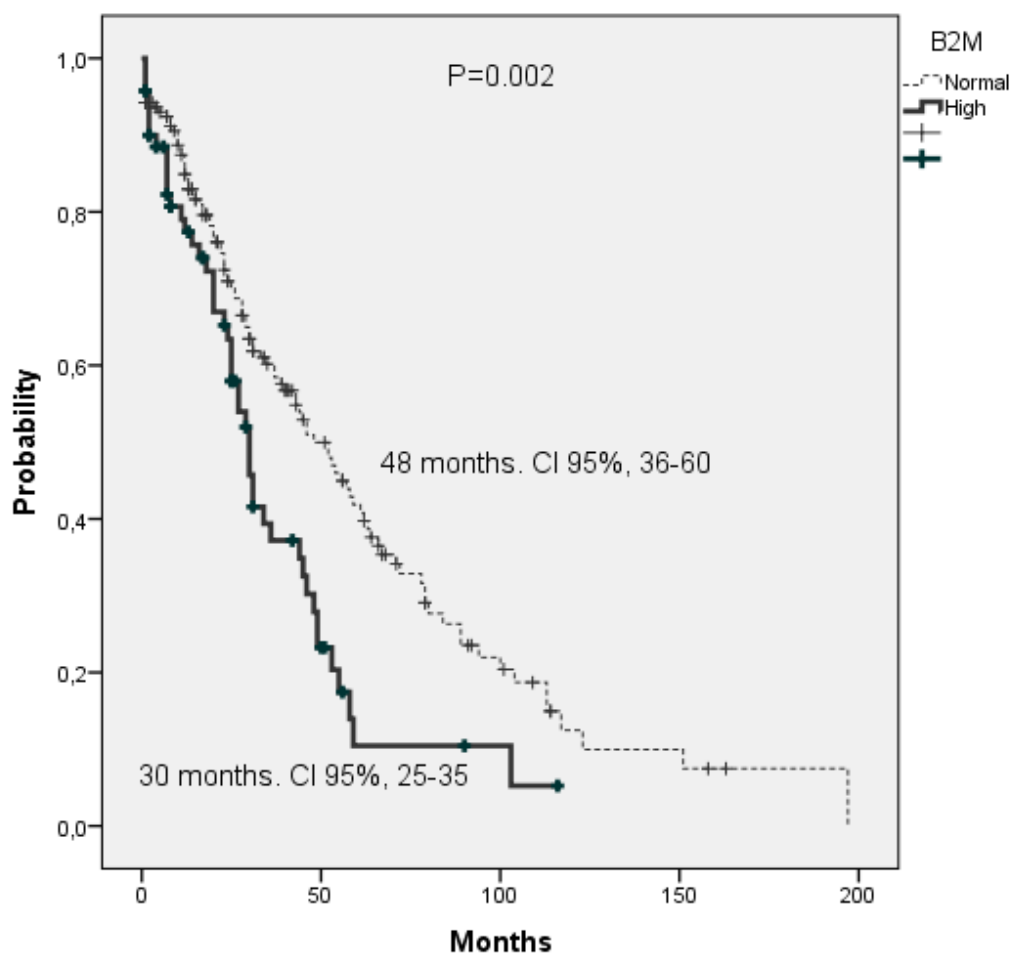

Figure 2 Kaplan-Meier curves for overall survival (OS) in 289 patients with +12 and: percentage of $+12(<v s \geq 60 \%$ ) (A); Binet stage (B); Lymphadenopathy (C); LDH (D); $\beta_{2}$ microglobulin (B2M) (E); and CD38 (F) (P<0.005; log-rank test). 


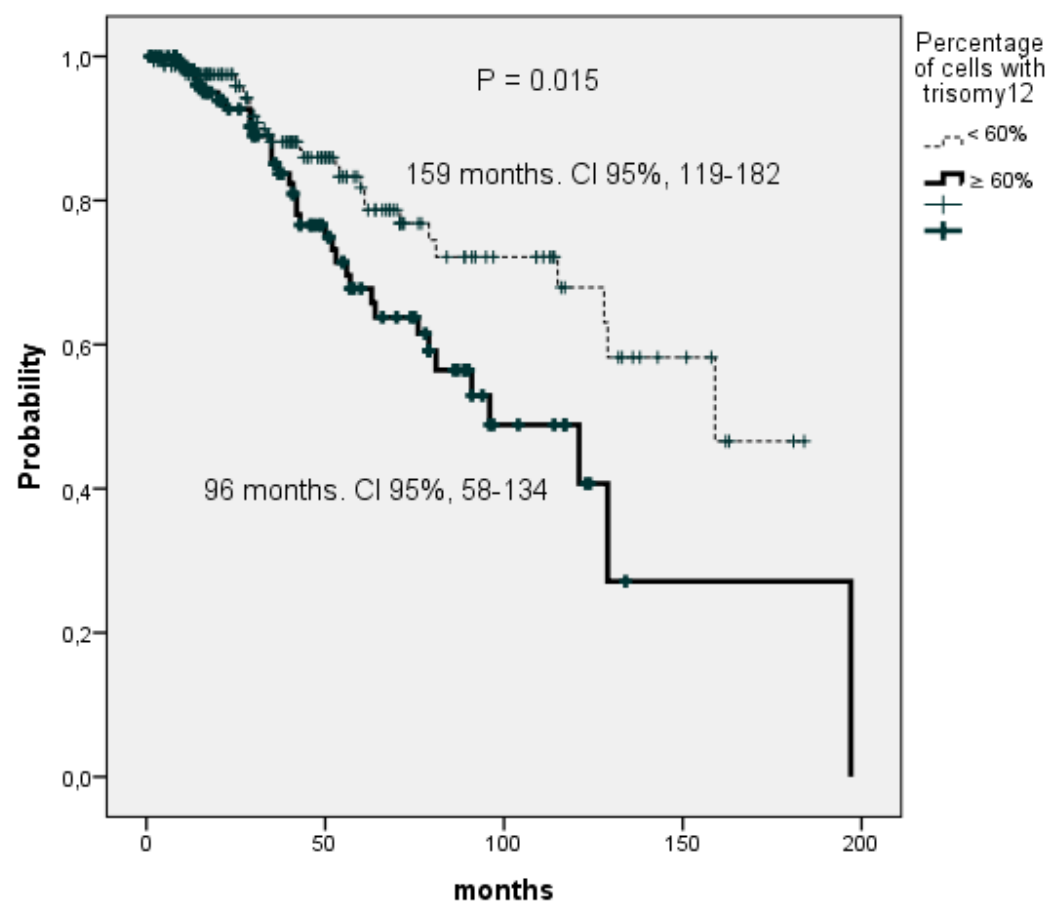

2B

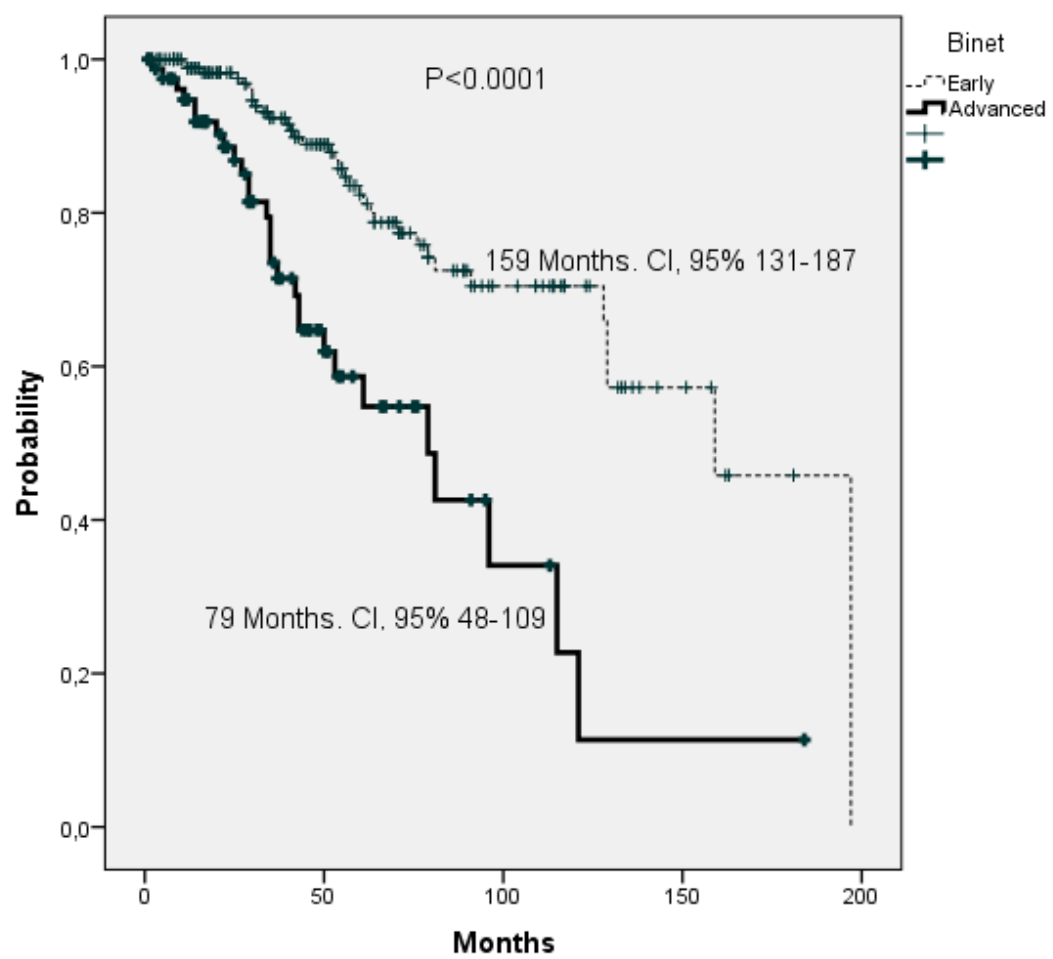

2C 


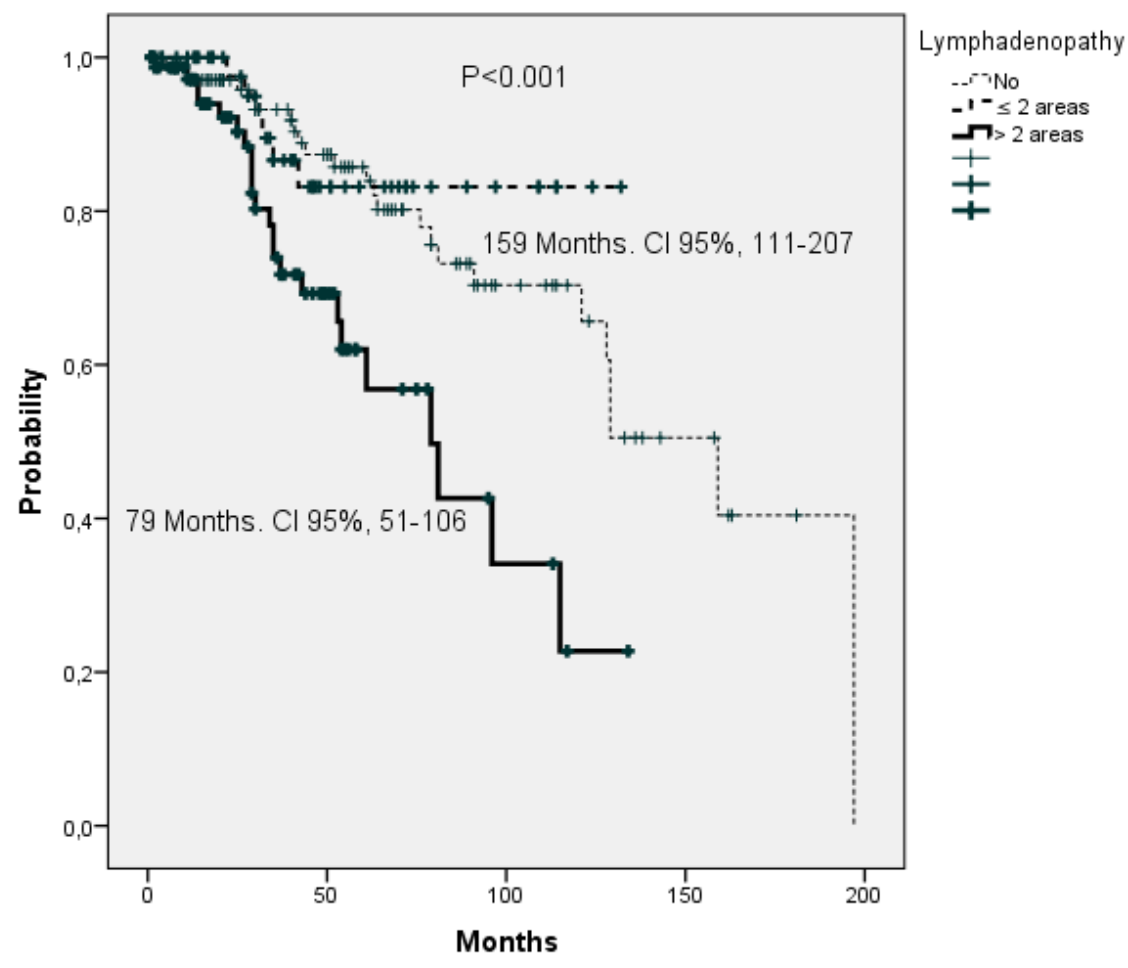

2D

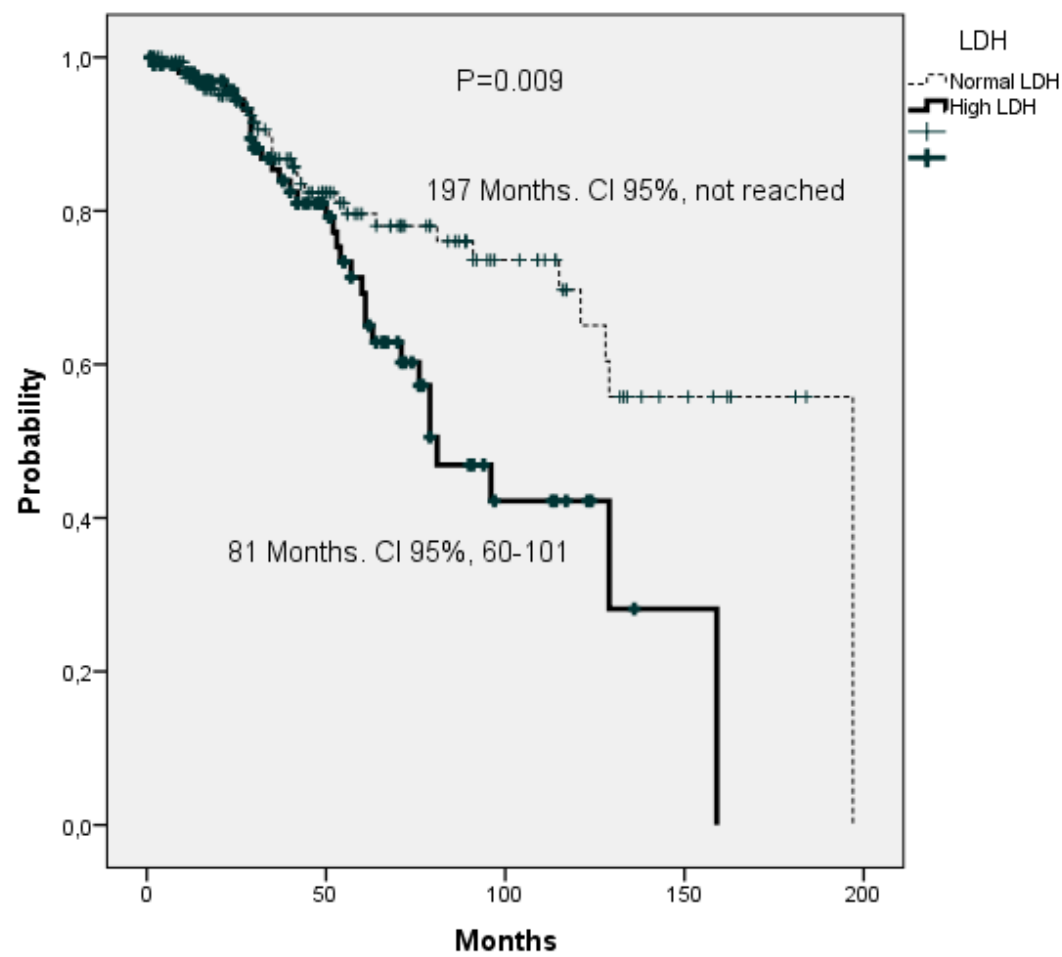

2E 


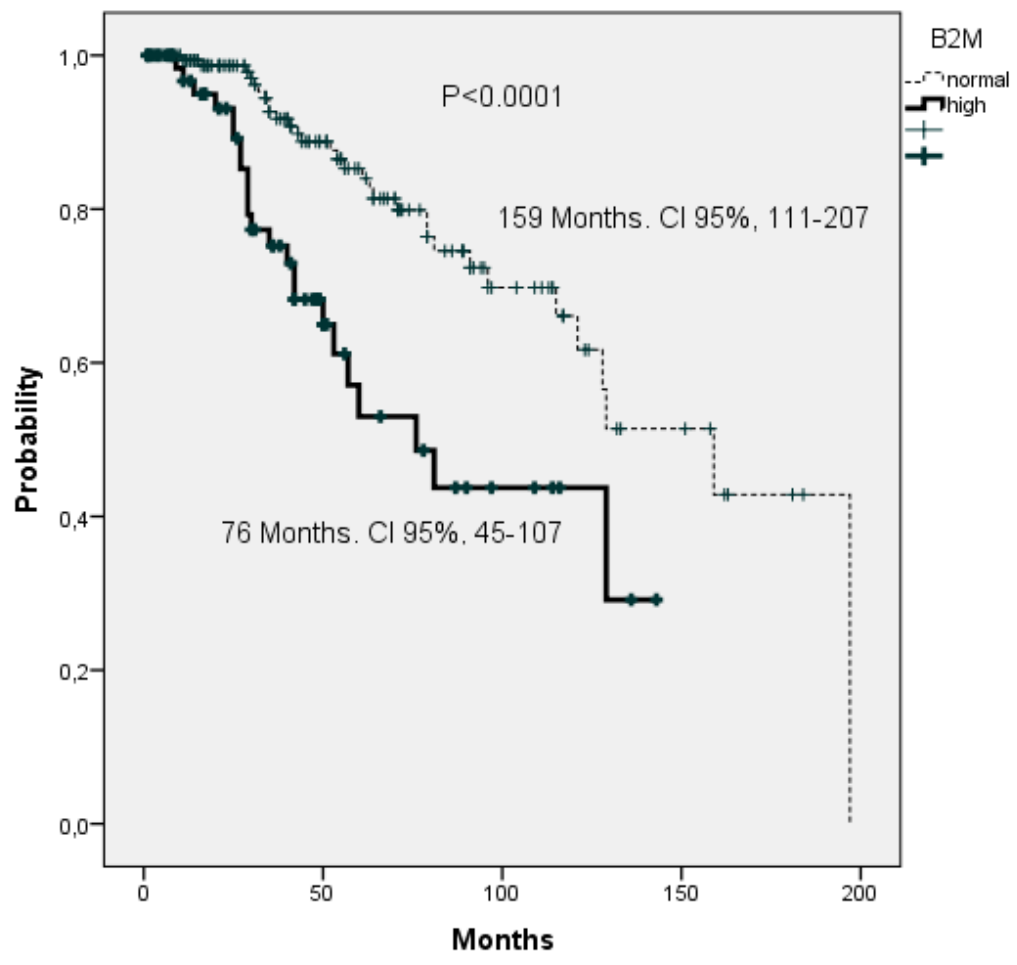

$2 \mathbf{F}$

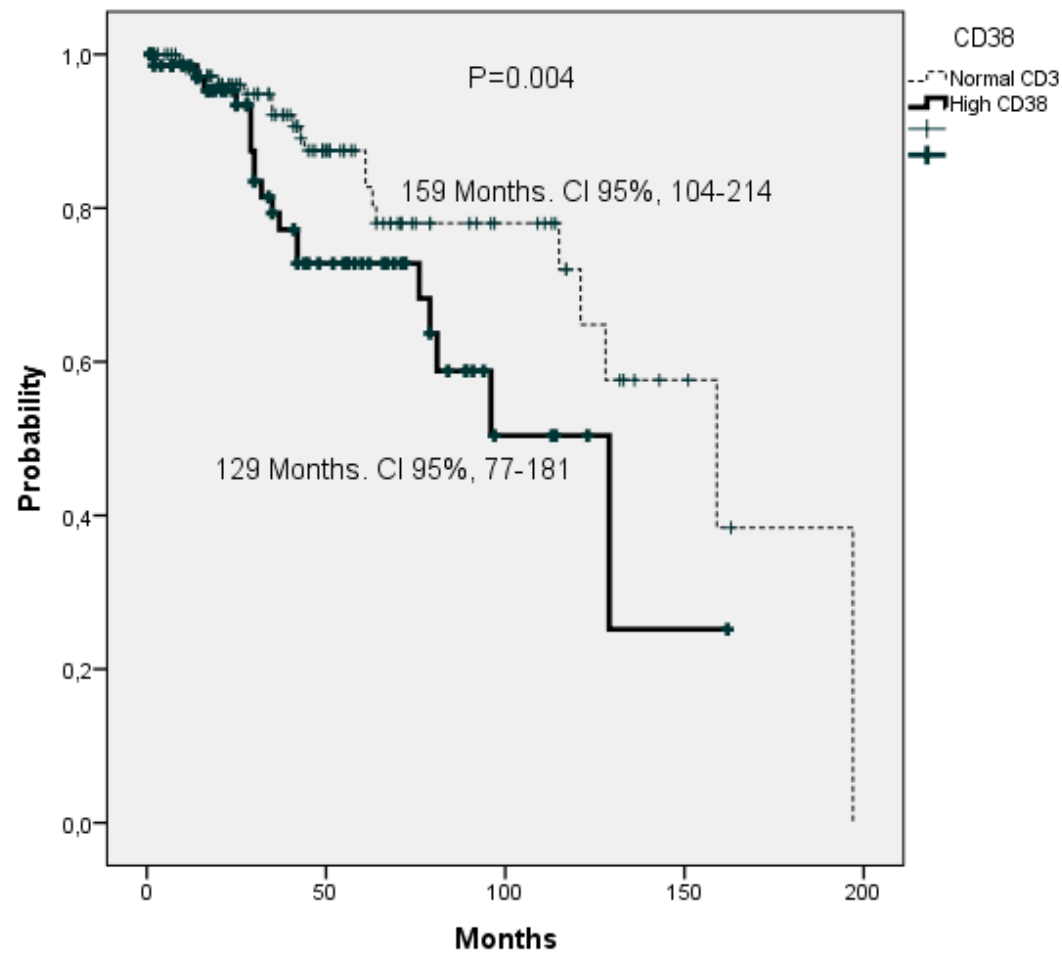

\section{Supporting information}

Table S1. Genomic aberrations assesed by FISH divided according to the percentage of cells carrying +12 . 


\begin{tabular}{|lcc|}
\hline & FISH $+\mathbf{1 2}<\mathbf{6 0 \%} \mathbf{n = 1 7 4}$ & FISH $+\mathbf{1 2} \geq \mathbf{6 0 \%} \mathbf{n = 1 1 5}$ \\
\hline Total other FISH aberrations & $\mathbf{3 4}$ & $\mathbf{2 2}$ \\
$13 q-(n=34)$ & 17 & 17 \\
$17 p-(n=11)$ & 8 & 3 \\
$11 q-(n=5)$ & 4 & 1 \\
$11 q-$ and 13q- $(n=3)$ & 3 & 0 \\
$17 p-$ and 13q- $(n=2)$ & 2 & 0 \\
$17 p-$ and 11q- $(n=1)$ & 0 & 1 \\
\hline Only +12 $(\mathbf{n = 2 3 3 )}$ & $\mathbf{1 4 0}$ & $\mathbf{9 3}$ \\
\hline
\end{tabular}

Figure S1. Kaplan-Meier curves for: time to first therapy (TTFT) in patients with +12 and 11q- (A); and overall survival (OS) in patients with +12 and 11q- (B).

\section{S1A}

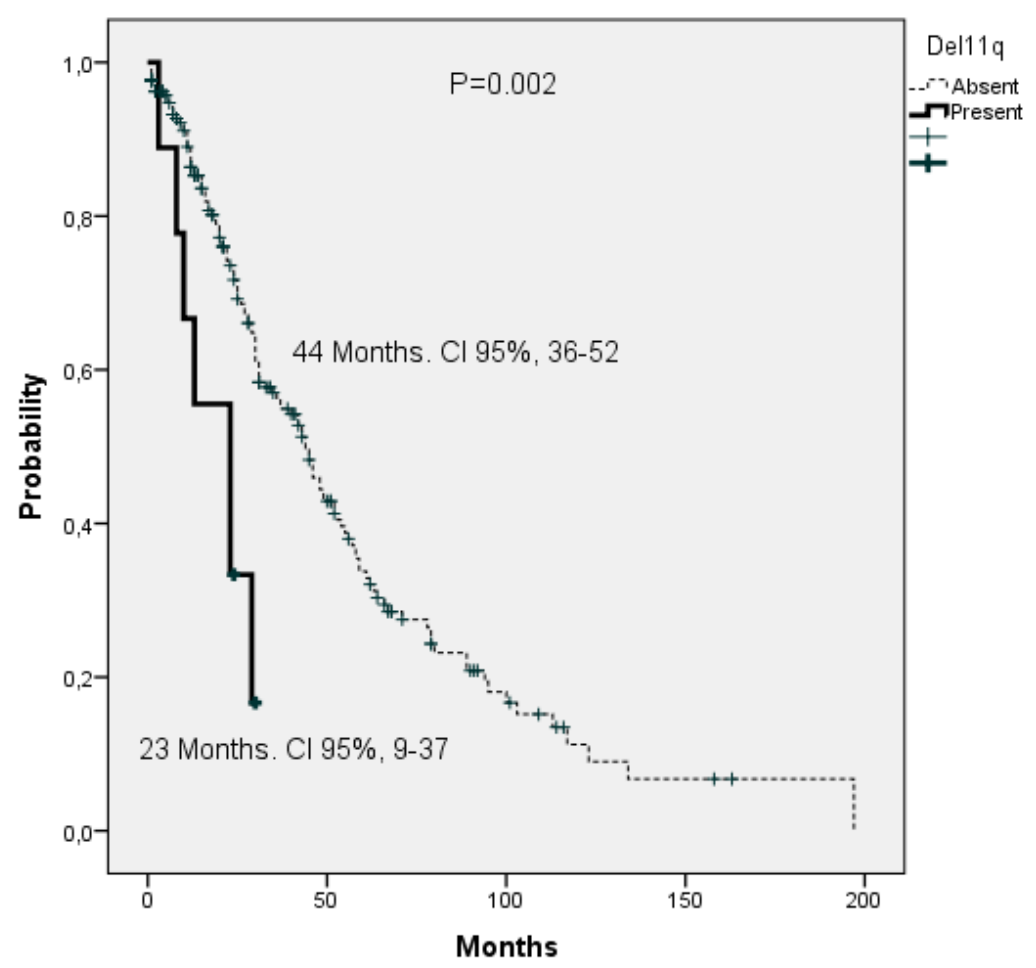

\section{S1B}




\section{Supporting information}

Table S1. Genomic aberrations assesed by FISH divided according to the percentage of cells carrying +12 .

\begin{tabular}{|lcc|}
\hline & FISH $+\mathbf{1 2}<\mathbf{6 0 \%} \mathbf{n = 1 7 4}$ & FISH +12 $\mathbf{2 6 0 \%} \mathbf{n = 1 1 5}$ \\
\hline Total other FISH aberrations & $\mathbf{3 4}$ & $\mathbf{2 2}$ \\
$13 q-(n=34)$ & 17 & 17 \\
$17 p-(n=11)$ & 8 & 3 \\
$11 q-(n=5)$ & 4 & 1 \\
$11 q-$ and 13q- $(n=3)$ & 3 & 0 \\
$17 p-$ and 13q- $(n=2)$ & 2 & 0 \\
$17 p-$ and 11q- $(n=1)$ & 0 & 1 \\
\hline Only $+\mathbf{1 2}(\mathbf{n}=\mathbf{2 3 3})$ & $\mathbf{1 4 0}$ & $\mathbf{9 3}$ \\
\hline
\end{tabular}

